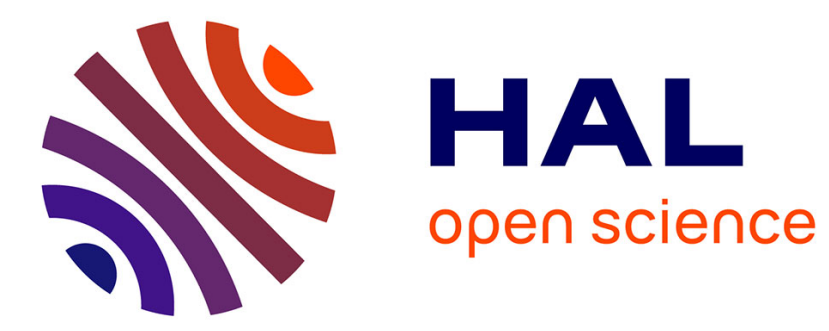

\title{
An Investigation of the Formation Mechanism of Copper(II) Carbodiimide
}

\author{
Richard Dronskowski, Xiaohui Liu
}

\section{To cite this version:}

Richard Dronskowski, Xiaohui Liu. An Investigation of the Formation Mechanism of Copper(II) Carbodiimide. Journal of Inorganic and General Chemistry / Zeitschrift für anorganische und allgemeine Chemie, 2009, 636 (1), pp.121. 10.1002/zaac.200900320 . hal-00528952

\section{HAL Id: hal-00528952 https://hal.science/hal-00528952}

Submitted on 23 Oct 2010

HAL is a multi-disciplinary open access archive for the deposit and dissemination of scientific research documents, whether they are published or not. The documents may come from teaching and research institutions in France or abroad, or from public or private research centers.
L'archive ouverte pluridisciplinaire HAL, est destinée au dépôt et à la diffusion de documents scientifiques de niveau recherche, publiés ou non, émanant des établissements d'enseignement et de recherche français ou étrangers, des laboratoires publics ou privés. 


\section{An Investigation of the Formation Mechanism of Copper(II) Carbodiimide}

\begin{tabular}{|c|c|}
\hline Journal: & Zeitschrift für Anorganische und Allgemeine Chemie \\
\hline Manuscript ID: & zaac. 200900320.R1 \\
\hline Wiley - Manuscript type: & Article \\
\hline $\begin{array}{r}\text { Date Submitted by the } \\
\text { Author: }\end{array}$ & 01-Sep-2009 \\
\hline Complete List of Authors: & $\begin{array}{l}\text { Dronskowski, Richard; Institute of Inorganic Chemistry, RWTH } \\
\text { Aachen } \\
\text { Liu, Xiaohui; Institute of Inorganic Chemistry, RWTH Aachen }\end{array}$ \\
\hline Keywords: & carbodiimide, copper(II), synthesis, crystal structure, copper(I) \\
\hline
\end{tabular}

\section{s) ScholaroNE \\ Manuscript Central}




\title{
An Investigation of the Formation Mechanism of Copper(II) Carbodiimide
}

\author{
Xiaohui Liu, Hari Puspitosari, and Richard Dronskowski* \\ Institute of Inorganic Chemistry, RWTH Aachen University \\ D-52056 Aachen, Germany
}

Dedicated to Professor Arndt Simon on the Occasion of his $70^{\text {th }}$ Birthday

\begin{abstract}
The formation mechanism of copper(II) carbodiimide in aqueous ammonia solution has been studied by synthetic and crystallographic means. The reduction of the starting $\mathrm{Cu}$ (II) solution leads to the synthesis of solid $\mathrm{Cu}(\mathrm{I})$ intermediates, and the crystal structures of the two new compounds $\mathrm{Cu}\left(\mathrm{NCNH}_{2}\right) \mathrm{Cl}(a=8.2925(4), b=3.7275(1), c=12.4534(4) \AA$, Pnma $)$ and the iso-structural $\mathrm{Cu}\left(\mathrm{NCNH}_{2}\right) \mathrm{Br}(a=8.406(3), b=3.9229(9), c=12.656(3) \AA$, Pnma $)$ have been elucidated. A further increase in $\mathrm{pH}$ value by adding more ammonia leads to the crystallization of two additional $\mathrm{Cu}(\mathrm{I})$ intermediates, $\mathrm{Cu}_{2} \mathrm{NCN}$ and the ammine adduct $\mathrm{Cu}_{4}(\mathrm{NCN})_{2} \mathrm{NH}_{3}$. The former can be also made by the thermal decomposition of the latter whereas mild oxidation of $\mathrm{Cu}_{4}(\mathrm{NCN})_{2} \mathrm{NH}_{3}$ leads to the formation of perfectly crystalline $\mathrm{CuNCN}$.
\end{abstract}

Keywords: carbodiimide / cyanamide / copper / crystal structure / reaction mechanism

\section{Introduction}

The motivation for carrying out exploratory syntheses in the fields of carbodiimides and cyanamides of the divalent magnetic transition metals $\left(d^{5}-d^{9}\right)$ is naturally linked with the structural and physical properties of these novel types of inorganic materials. ${ }^{[1-7]}$ Among them, black powderous copper carbodiimide, $\mathrm{CuNCN}$, stands for the nitrogen-based analogue of $\mathrm{CuO},{ }^{[2,5]}$ and $\mathrm{CuNCN}$ was first made in large, phase-pure and well-crystallized quantities only five years ago. ${ }^{[2]}$ The synthetic difficulty lies in the fact that aforementioned $\mathrm{M}^{2+}$ transitionmetal ions prefer to form cyanamide complexes in aqueous solution ${ }^{[8,9]}$ such that, as a charac- 
teristic example, $\mathrm{Cu}^{2+}$ cations merely form coordination complexes like $\left[\mathrm{Cu}\left(\mathrm{NCNH}_{2}\right)_{4}\right]^{2+}$ from which the protons can not be fully removed. The brute-force alternative of a (strong) basic aqueous $\mathrm{Cu}$ (II) solution reacting with anionic cyanamide units, however, yields a black material whose amorphous nature renders its structure determination impossible. ${ }^{[10,11]}$ As said before, we were fortunate to discover a new synthetic approach for perfectly crystalline CuNCN a while ago. ${ }^{[2]}$ The two-step method is essentially based on an ammine $\mathrm{Cu}(\mathrm{I})$ cyanamide compound, $\mathrm{Cu}_{4}(\mathrm{NCN})_{2} \mathrm{NH}_{3}$, which can be obtained from the mild reaction of $\left[\mathrm{Cu}\left(\mathrm{NH}_{3}\right)_{2}\right]^{+}$and $\mathrm{H}_{2} \mathrm{NCN}$ under aqueous ammonia conditions. ${ }^{[12]}$ The likewise mild oxidation of $\mathrm{Cu}_{4}(\mathrm{NCN})_{2} \mathrm{NH}_{3}$ then yields the target phase $\mathrm{CuNCN}$. Schematically, the entire procedure may be summarized as follows:

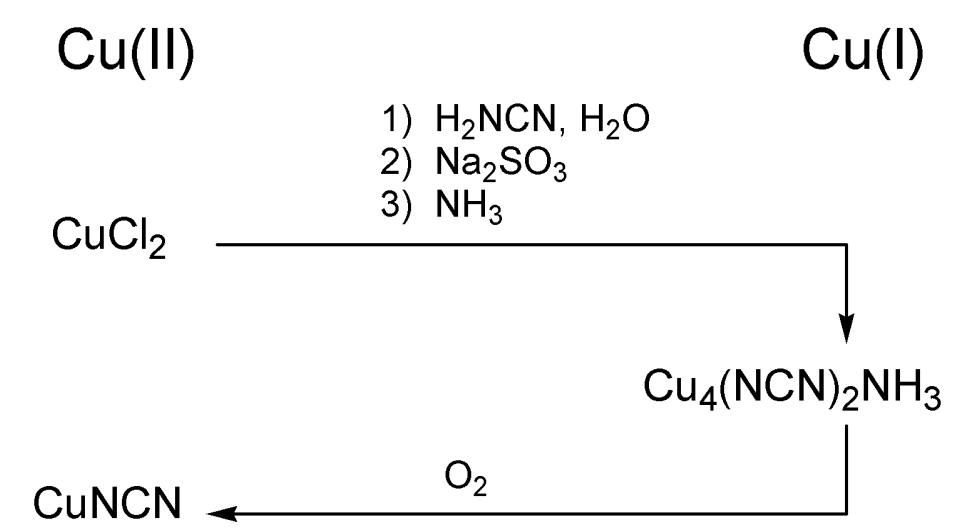

In order to come up with a less formal description, we have now examined the reaction mechanism of $\mathrm{CuNCN}$ formation in more detail. By doing so, the syntheses and crystal structures of two new solid-state copper(I) halide complexes have been accomplished, together with yet another new $\mathrm{Cu}(\mathrm{I})$ cyanamide solid-state material.

\section{Experimental Section}

In order to elucidate possible reaction pathways, alternative syntheses were tested, namely a total of six different preparations.

Experiment 1: A mixture of $\mathrm{CuCl}_{2} \cdot 2 \mathrm{H}_{2} \mathrm{O}(1.71 \mathrm{~g}, 10 \mathrm{mmol})$ and cyanamide $\mathrm{H}_{2} \mathrm{NCN}(0.84 \mathrm{~g}$, $20 \mathrm{mmol})$ was stirred at room temperature in water $(10 \mathrm{~mL})$ under argon gas. A solution of $\mathrm{Na}_{2} \mathrm{SO}_{3}(1.26 \mathrm{~g}, 10 \mathrm{mmol})$ in $10 \mathrm{~mL}$ water was added dropwise to the above mixture resulting in colorless needle-like crystals of the new phase $\mathrm{Cu}\left(\mathrm{NCNH}_{2}\right) \mathrm{Cl}(\mathbf{1 a})$ which were then filtered and dried under vacuum. Analytical data $(\%)$ for $\mathrm{Cu}\left(\mathrm{NCNH}_{2}\right) \mathrm{Cl}(141.04 \mathrm{~g} / \mathrm{mol}): \mathrm{Cu} 44.76$ (calc. 45.05); C 8.32 (8.52); H 2.01 (1.42); N 19.34 (19.86). 


\section{X-ray Crystallography}

Structure data of 1a. The X-ray diffraction data were recorded at room temperature using a G670 Imageplate Guinier diffractometer (Huber, Rimsting) equipped with a Johansson Ge monochromator for $\mathrm{Cu} \mathrm{K \alpha} \alpha_{1}$ radiation and a flat sample holder in the $2 \theta$ range between 6 and $100^{\circ}$. The XRPD pattern of $\mathbf{1 a}$ indicated a pure phase such that its structure was determined using Rietveld analysis based upon the iso-structural model of $\mathbf{1 b}$. The FULLPROF program package $^{[21]}$ was used with a pseudo-Voigt profile function, and the background data were manually subtracted by linear interpolation. Because of strongly preferred orientation and likewise asymmetric Bragg peaks, the atomic distances of $\mathrm{Cu}-\mathrm{N}$ and $\mathrm{C}-\mathrm{N}$ and the $\mathrm{N}-\mathrm{C}-\mathrm{N}$ angle had to be soft-restrained to yield reasonable bond lengths and a more reliable refine- 
ment. Likewise, all $\mathrm{H}$ positional parameters were fixed to $\mathrm{N}-\mathrm{H}$ distances of $0.89 \AA$ A. Empirical formula $\mathrm{CH}_{2} \mathrm{ClCuN}_{2}, M_{\mathrm{r}}=141.04$, orthorhombic, Pnma, $a=8.2925(4), b=3.7275(1), c=$ 12.4534(4) $\AA, V=384.48(2) \AA^{3}, Z=4$. The residual values arrived at $0.072\left(R_{\mathrm{p}}\right), 0.102\left(R_{\mathrm{wp}}\right)$, and $0.18\left(R_{\mathrm{Bragg}}\right)$ for a total of 22 variables, 4 restraints and 248 Bragg reflections.

Structure data of $\mathbf{1 b}$. A complete set of X-ray intensities was collected with a Bruker SMART-CCD diffractometer using graphite-monochromatized Mo K $\alpha$ radiation at $T=20(1)$ ${ }^{\circ} \mathrm{C}$ and with the aid of the SMART and SAINT software packages. ${ }^{[22]}$ A total Ewald sphere was collected and carefully corrected with respect to absorption using the empirical SADABS method. The crystal structure was then solved by Direct Methods and refined by alternating cycles of difference Fourier syntheses and full-matrix least-squares refinements with SHELXS-97 and SHELXL-97. ${ }^{[23]}$ All non-hydrogen atoms were subjected to anisotropic refinement. All hydrogen atoms were located by difference Fourier synthesis and refined using a riding model with restrained $\mathrm{N}-\mathrm{H}$ distances of $0.86-0.89 \AA$ and with $U_{\text {iso }}(\mathrm{H})$ values of $1.2 \times$ $U_{\text {eq }}(\mathrm{N} 2)$. Empirical formula $\mathrm{CH}_{2} \mathrm{BrCuN}_{2}, M_{\mathrm{r}}=185.49$, orthorhombic, Pnma, $a=8.406(3), b=$ 3.9229(9), $c=12.656(3) \AA, V=417.4(2) \AA^{3}, Z=4$, size $=0.15 \times 0.05 \times 0.04 \mathrm{~mm}^{3}, \theta_{\text {range }}=2.9$ to $24.8^{\circ}, 3039$ reflections $\left(R_{\mathrm{int}}=0.126\right), \mathrm{GOF}=0.862, R_{1}(I>2 \sigma(I))=0.0639, w R_{2}(I>2 \sigma(I))$ $=0.130$; CSD-420807. All important numerical details of the refinements of $\mathbf{1 a}$ and $\mathbf{1 b}$ may be found in Table 1. Positional and displacement parameters are listed in Table 2.

\section{Results and Discussion}

Reaction procedure. The reported synthesis of $\mathrm{CuNCN}$ is, in fact, a one-pot reaction. In this study, the synthetic procedure has been interrupted after each proposed intermediate species. In order to characterize these intermediates, additional reactions have been carried out.

At first, $\mathrm{Cu}^{2+}$ ions have been reduced by $\mathrm{Na}_{2} \mathrm{SO}_{3}$ in an excess (two equimolar) of $\mathrm{H}_{2} \mathrm{NCN}$ solution under inert atmosphere. For $\mathrm{CuCl}_{2}$ as a starting substance, the pure intermediate $\mathrm{Cu}\left(\mathrm{NCNH}_{2}\right) \mathrm{Cl}$ (1a) has been obtained. For the case of $\mathrm{CuBr}_{2}$, the bromine analogue $\mathrm{Cu}\left(\mathrm{NCNH}_{2}\right) \mathrm{Br}(\mathbf{1 b})$ has been found together with a small amount of $\mathrm{CuBr}$. This finding may be a consequence of the 25 times smaller solubility product of $\mathrm{CuBr}\left(K_{\mathrm{sp}}=4.15 \times 10^{-8} \mathrm{~mol}^{2}\right.$ $\left.\mathrm{L}^{-2}\right)$ than that of $\mathrm{CuCl}\left(1.02 \times 10^{-6} \mathrm{~mol}^{2} \mathrm{~L}^{-2}\right)$. Fortunately, single crystals of $\mathbf{1 b}$ have been isolated for crystal structure determination. Although 1a was not obtained as a single crystal, the XRPD patterns for $\mathbf{1 a}$ and $\mathbf{1 b}$ clearly show that they are iso-structural. 
After reducing all $\mathrm{Cu}(\mathrm{II})$ in $\mathrm{H}_{2} \mathrm{NCN}$ solution by the use of $\mathrm{Na}_{2} \mathrm{SO}_{3}$, a concentrated ammonia solution was added until $\mathrm{pH}>10$ which resulted in the formation of white $\mathrm{Cu}_{4}(\mathrm{NCN})_{2} \mathrm{NH}_{3}$ (2). By careful observation it appears that, along with adding the ammonia, a yellow - instead of white - precipitation starts at the very beginning, which then rapidly changes to white. Thus, the attempt to isolate the yellow compound utilizes a buffer solution, that is, a one-molar $\mathrm{NH}_{3} \cdot \mathrm{NH}_{4} \mathrm{Cl}$ mixture with a $\mathrm{pH}$ around $8-9$, and this, in fact, leads to a solid mixture of $\mathbf{2}$ and $\mathrm{Cu}_{2} \mathrm{NCN}$ (3). The chemical similarity between $\mathbf{2}$ and $\mathbf{3}$ is obvious because the heat treatment of $2\left(150{ }^{\circ} \mathrm{C}\right.$, vacuum, $\left.48 \mathrm{~h}\right)$ leads to a pure yellow powder of $\mathbf{3}$, together with $\mathrm{NH}_{3}$ gas inside the cooling trap. Elemental analysis agrees with the theoretical composition of $\mathrm{Cu}_{2} \mathrm{NCN}$. Comparing the infrared spectra of $\mathbf{3}$ with the compilation of metalcarbodiimides/cyanamides provided by Reckeweg and Simon, ${ }^{[7]}$ it is obvious that 3 not only exhibits strong carbodiimide-type asymmetrical vibrations, $v_{\text {as }}(\mathrm{NCN})=2138 / 2193 \mathrm{~cm}^{-1}$, plus a strong deformation vibration, $\delta(\mathrm{NCN})=655 \mathrm{~cm}^{-1}$, but also the symmetrical $v_{\mathrm{s}}$ band $(1182$ $\mathrm{cm}^{-1}$ ) which would be allowed for the less symmetrical cyanamide $[\mathrm{N}-\mathrm{C} \equiv \mathrm{N}]^{2-}$ anion and IRforbidden for the $[\mathrm{N}=\mathrm{C}=\mathrm{N}]^{2-}$ carbodiimide unit. However, no good structural model has been found so far to allow for a reasonable crystal-structure refinement of the XRPD pattern.

In case a small amount of air was allowed to enter the mixture of $\mathbf{2}$ and the cyanamide solution, the solution itself changed rapidly to blue; the oxidation of the white precipitate $\mathbf{2}$, however, proceeded very slowly to eventually give black $\mathrm{CuNCN}$. The latter phase forms with an exceptionally good crystallinity over night (Figure 1).

Mechanism discussion. We have tried to reduce the surplus amount of $\mathrm{H}_{2} \mathrm{NCN}$ from four to two equimoles compared to that of $\mathrm{Cu}^{2+}$ ions as described in experiment 1 . Nonetheless, essentially the same results were observed with the only exception of a slightly reduced yield of $\mathrm{CuNCN}$ from lower-concentrated $\mathrm{H}_{2} \mathrm{NCN}$ solutions. If an equimolar relation of $\mathrm{Cu}^{2+}$ and $\mathrm{H}_{2} \mathrm{NCN}$ was used at the very beginning, insoluble $\mathrm{CuCl}$ was found together with $\mathbf{1 a}$; the latter phase will not, however, influence the purity of final product simply because $\mathrm{CuCl}$ later also dissolves in concentrated ammonia solution. Taking into account that $\mathrm{Cu}(\mathrm{II})$ must be fourcoordinated by electronegative atoms such as $\mathrm{O}$ and $\mathrm{N}$ - for example, as given in the complex $\left[\mathrm{Cu}\left(\mathrm{NCNH}_{2}\right)_{4}\right]^{2+}$ cation $^{[9]}$ - we therefore tentatively conclude that the complex ion $\left[\mathrm{Cu}\left(\mathrm{NCNH}_{2}\right)_{2}\left(\mathrm{H}_{2} \mathrm{O}\right)_{2}\right]^{2+}$ has been formed:

$$
\mathrm{CuCl}_{2}+2 \mathrm{H}_{2} \mathrm{O}+2 \mathrm{H}_{2} \mathrm{NCN} \stackrel{\mathrm{pH}=4}{\longrightarrow}\left[\mathrm{Cu}\left(\mathrm{NCNH}_{2}\right)_{2}\left(\mathrm{H}_{2} \mathrm{O}\right)_{2}\right]^{2+}+2 \mathrm{Cl}^{-}
$$


The reduction of $\mathrm{Cu}(\mathrm{II})$ in the presence of coordinating ligands is an established method to obtain copper(I) complexes, ${ }^{[13,14]}$ but such reactions are typically performed in organic solvents instead of aqueous solution because of the low equilibrium concentrations of $\mathrm{Cu}(\mathrm{I})$ and its instability with respect to disproportion $\left(2 \mathrm{Cu}^{\mathrm{I}}=\mathrm{Cu}^{0}+\mathrm{Cu}^{\mathrm{II}}\right)$. The latter stability problem in aqueous solution depends very strongly on the nature of the ligand which should have $\pi$ acceptor character to stabilize $\mathrm{Cu}^{+}$. In this respect, $\mathrm{H}_{2} \mathrm{NCN}$ is indeed a suitable ligand being able to form the new solid-state halide complexes $\mathbf{1 a}$ or $\mathbf{1 b}$ under strongly acidic condition (reaction 2) and even to allow for the existence of the ammonia complex $\mathbf{2}$ under strongly basic conditions (reaction 4 , see below).

$$
\begin{aligned}
2\left[\mathrm{Cu}\left(\mathrm{NCNH}_{2}\right)_{2}\left(\mathrm{H}_{2} \mathrm{O}\right)_{2}\right]^{2+}+ & 2 \mathrm{Cl}^{-}+\mathrm{SO}_{3}{ }^{2-} \longrightarrow \\
& 2 \mathrm{Cu}\left(\mathrm{NCNH}_{2}\right) \mathrm{Cl}+2 \mathrm{H}_{2} \mathrm{NCN}+\mathrm{SO}_{4}{ }^{2-}+3 \mathrm{H}_{2} \mathrm{O}+2 \mathrm{H}^{+}
\end{aligned}
$$

The adjustment of the $\mathrm{pH}$ value plays a very important role in the entire procedure; in fact, the change of the $\mathrm{pH}$ value leads to the formation of four different compounds. While the $\mathrm{pH}$ value of the starting reaction mixture is about 4 , the addition of the reducing agent leads to reaction 2 taking place in which the $\mathrm{pH}$ drops to about 1 . Thus, the two solid-state complexes 1a and $\mathbf{1 b}$ can only exist under acidic conditions. Upon adding ammonia to the reaction solution and thereby attaining weakly basic conditions, the $\mathrm{H}_{2} \mathrm{NCN}$ species is deprotonated which leads to the synthesis of $\mathbf{3}$ as shown in reaction 3:

$2 \mathrm{Cu}\left(\mathrm{NCNH}_{2}\right) \mathrm{Cl}+2 \mathrm{NH}_{3} \longrightarrow \mathrm{Cu}_{2} \mathrm{NCN}+\mathrm{H}_{2} \mathrm{NCN}+2 \mathrm{NH}_{4} \mathrm{Cl}$

When the $\mathrm{pH}$ value exceeds 10, only 2 exists, a consequence of the law of mass action. Alternatively expressed, the structural stability of $\mathrm{Cu}_{4}(\mathrm{NCN})_{2} \mathrm{NH}_{3}(2)$ at room temperature exceeds the one of $\mathrm{Cu}_{2} \mathrm{NCN}$ (3). Likewise, it is not difficult to understand that the application of higher temperatures leads to the removal of weakly coordinating $\mathrm{NH}_{3}$ from $\mathbf{2}$, thereby forming 3 by thermal decomposition (reaction 4 ).

$2 \mathrm{Cu}_{2} \mathrm{NCN}+\mathrm{NH}_{3} \frac{\mathrm{NH}_{3} \cdot \mathrm{H}_{2} \mathrm{O} \mathrm{pH}>10}{150^{\circ} \mathrm{C}} \mathrm{Cu}_{4}(\mathrm{NCN})_{2} \mathrm{NH}_{3}$

The final oxidation step takes place under strongly basic (aqueous ammonia) conditions which is more effective and ensures the purity of the final product $\mathrm{CuNCN}$ by forming 
$\left[\mathrm{Cu}\left(\mathrm{NH}_{3}\right)_{4}\right]^{2+}$. As said before, stable copper(I) complexes are not very common although plenty of copper(I) compounds have been reported in recent years. ${ }^{[13-17]}$ To the best of our knowledge, the use of a stable copper(I) complex to synthesize a copper(II) target compound is very rare. The main advantage of our method is that the oxidation of suspended $\mathbf{2}$ is taking place quite slowly in order to form well-crystallized CuNCN (reaction 5).

$$
\mathrm{Cu}_{4}(\mathrm{NCN})_{2} \mathrm{NH}_{3}+2 \mathrm{H}_{2} \mathrm{NCN}+\mathrm{O}_{2} \longrightarrow 4 \mathrm{CuNCN}+2 \mathrm{H}_{2} \mathrm{O}
$$

Crystal structure. A large number of different structures for $\mathrm{Cu}(\mathrm{I})$ halide complexes have been identified depending on the nature of ligand as well as the composition. ${ }^{[14-17]}$ In the present case, the structures of $\mathbf{1 a}$ and $\mathbf{1 b}$ are of the same type, despite the fact that $\mathrm{Cu}\left(\mathrm{NH}_{3}\right) \mathrm{Cl}$ forms linear $\mathrm{NH}_{3}-\mathrm{Cu}-\mathrm{Cl}$ units whereas $\mathrm{Cu}\left(\mathrm{NH}_{3}\right) \mathrm{Br}$ does not exist; instead, the phase $\left[\mathrm{Cu}\left(\mathrm{NH}_{3}\right)_{2}\right] \mathrm{Br}$ has been described. ${ }^{[14]}$ The structures of $\mathbf{1 a}$ and $\mathbf{1 b}$ may be well compared with the one of copper(I) iodide pyridine, $\left[\mathrm{CuI}\left(\mathrm{NC}_{5} \mathrm{H}_{5}\right)\right]_{4}$, with a four-coordinated $\mathrm{Cu}(\mathrm{I})$ to which three halides and one $\mathrm{N}$ from the ligand bonds. ${ }^{[18]}$ In the case of $\mathbf{1 a}$ and $\mathbf{1 b}$, one finds infinite one-dimensional chains of $\left[-\mathrm{Cu}\left(\mathrm{NCNH}_{2}\right) \mathrm{X}-\right]_{\mathrm{n}}$ (see Figure 2) which consist of tetrahedrally coordinated $\mathrm{Cu}(\mathrm{I})$ ions, that is, bonded to three halide atoms $(2 \times 2.47(3)$ and $1 \times 2.40(3) \AA$ for $\mathrm{Cu}-\mathrm{Cl}$ in $\mathbf{1 a} ; 2 \times 2.536(2)$ and $1 \times 2.510(3) \AA$ for $\mathrm{Cu}-\mathrm{Br}$ in $\mathbf{1 b})$ and to one nitrogen atom from the $\mathrm{C}-\mathrm{N}$ single bond side $(\mathrm{Cu}-\mathrm{N}=2.04(3)$ in $\mathbf{1 a}$ and 1.92(2) $\AA$ in $\mathbf{1 b})$ that stems from the cyanamide molecule (see Figure 3 ). The $\mathrm{H}_{2} \mathrm{NCN}$ unit shows the typical cyanamide shape with one single $\mathrm{C}-\mathrm{N}$ bond of 1.35(2) $\AA$ and one triple bond of 1.11(2) $\AA$ refined for $\mathbf{1 b}$; for the 1a Rietveld-based structure, the carbon-nitrogen bond lengths had to refined with restraints (1.10(4) and 1.27(4) $\AA$ ) but the structure of $\mathrm{H}_{2} \mathrm{NCN}$ should not have too much deviation. As is evident from Table 3, there exist no strong hydrogen bonds in the crystals. Comparing with much shorter $\mathrm{Cu}-\mathrm{Cu}$ distances of 2.979(1) $\AA$ in $\mathrm{Cu}\left(\mathrm{NH}_{3}\right) \mathrm{Cl}^{[14]}$ and 2.453(1) $\mathrm{\AA}$ in $\mathrm{Cu}_{2}\left(\mathrm{C}_{7} \mathrm{~N}_{3} \mathrm{H}_{12}\right)_{2},{ }^{[19]}$ the $\mathrm{Cu}-\mathrm{Cu}$ distances in $\mathbf{1 a}$ and $\mathbf{1 b}$ are about $3.0 \AA$ and indicate nonbonding $\mathrm{Cu}-\mathrm{Cu}$ interactions. ${ }^{[20]}$

It is quite interesting that the NCN cores of the cyanamide molecules exhibit different structures in the two intermediates $\mathbf{1 a}$ and $\mathbf{2}$ as compared with $\mathrm{CuNCN}$. In $\mathrm{Cu}\left(\mathrm{H}_{2} \mathrm{NCN}\right) \mathrm{Cl}$, we have a cyanamide molecule with a single $\mathrm{C}-\mathrm{N}$ and a triple $\mathrm{C} \equiv \mathrm{N}$ bonds (see above), and the same is found for $\mathrm{Cu}_{4}(\mathrm{NCN})_{2} \mathrm{NH}_{3}$ despite containing an anion. In $\mathrm{CuNCN}$, the "harder" $\mathrm{Cu}(\mathrm{II})$ atom bonds to the $\mathrm{NCN}^{2-}$ unit which exists in the carbodiimide shape, namely with two double $\mathrm{C}=\mathrm{N}$ bonds. Obviously, the molecular shape depends on the counter cation, the coordination motif and also the crystal packing. 


\section{Conclusions}

The reaction mechanism of the formation of copper(II) carbodiimide has been analyzed by using chemical and crystallographic means. The results indicate the presence of at least three new intermediates, two of which have been characterized in terms of their crystal structures. The crystal-structural determination of $\mathrm{Cu}_{2} \mathrm{NCN}$ is still in progress. The entire reaction scheme may be formulated as follows:

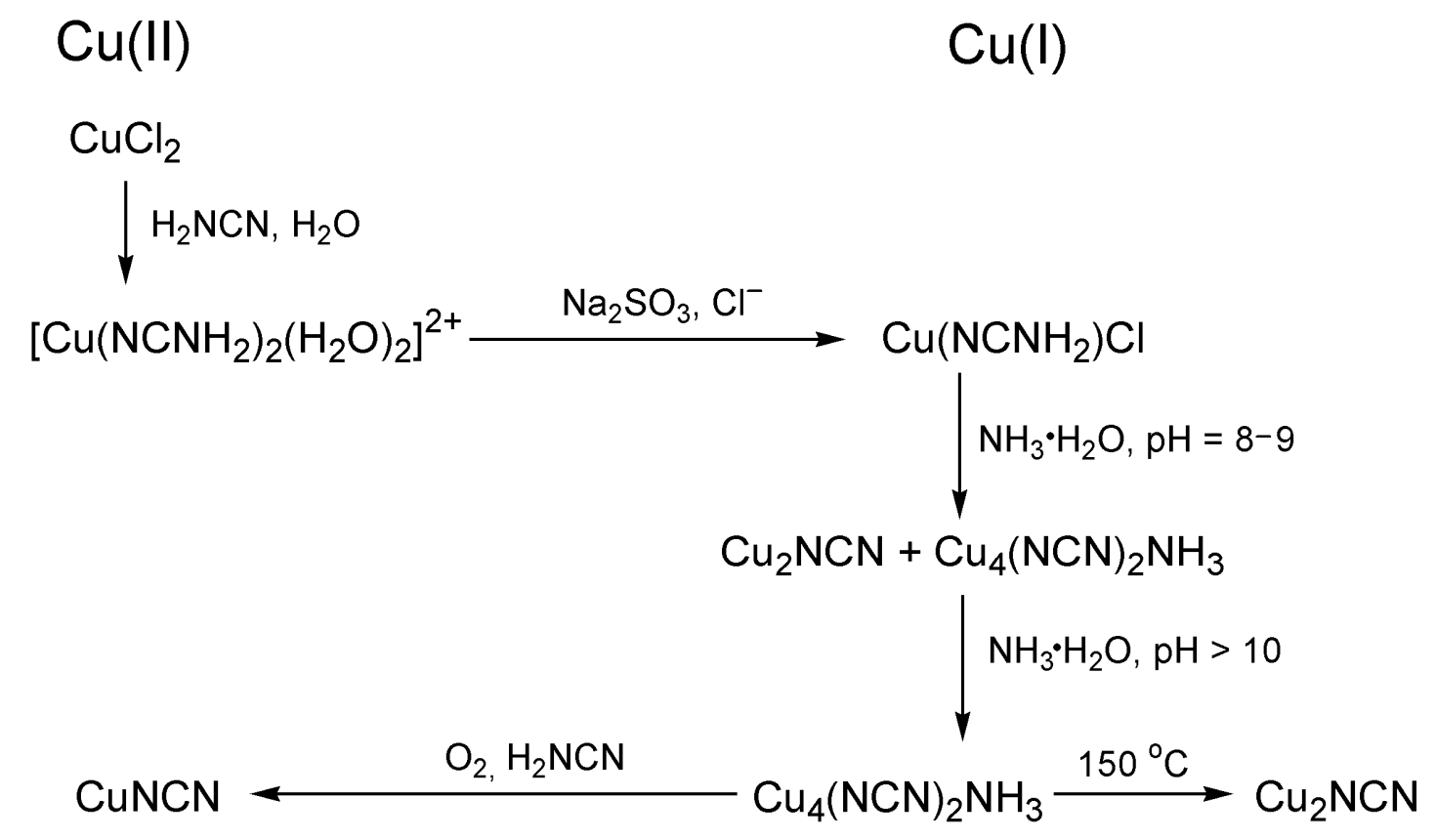

\section{References}

1. X. Liu, M. Krott, P. Müller, C. Hu, H. Lueken, R. Dronskowski, Inorg. Chem. 2005, 44, 3001.

2. X. Liu, M. A. Wankeu, H. Lueken, R. Dronskowski, Z. Naturforsch. 2005, 60b, 593.

3. M. Krott, X. Liu, P. Müller, R. Dronskowski, J. Solid State Chem. 2007, 180, 307.

4. M. Krott, X. Liu, B. P. T. Fokwa, M. Speldrich, H. Lueken, R. Dronskowski, Inorg. Chem. 2007, 46, 2204.

5. X. Liu, R. Dronskowski, R. K. Kremer, M. Ahrens, C. Lee, M. Whangbo, J. Phys. Chem. C 2008, 112, 11013.

6. X. Liu L. Stork, M. Speldrich, H. Lueken, R. Dronskowski, Chem. Eur. J. 2009, 15, 1558.

7. O. Reckeweg, A. Simon, Z. Naturforsch. 2003, 58b, 1097. 
8. X. Liu, P. Kroll, R. Dronskowski, Z. Anorg. Allg. Chem. 2001, 627, 1882.

9. X. Liu, R. Dronskowski, Z. Kristallogr. NCS 2002, 217, 118.

10. S. K. Deb, A. D. Yoffe, Trans. Faraday Soc. 1958, 55, 106.

11. K. M. Adams, M. J. Cooper, M. J. Sole, Acta Crystallogr. 1964, 17, 1449.

12. X. Liu, P. Müller, R. Dronskowski, Z. Anorg. Allg. Chem. 2005, 631, 1071.

13. M. A. Galindo, D. Amantia, W. Clegg, R. W. Harrington, R. J. Eyre, J. P. Goss, P. R. Briddon, W. McFarlane, A. Houlton, Chem. Commun. 2009, 2833.

14. G. Margraf, J. W. Bats, M. Bolte, H.W. Lerner, M. Wagner, Chem. Commun. 2003, 956.

15. C. Nather, J. Greve, I. Jess, Solid State Sciences 2002, 4, 813.

16. B. J. Fox, Q. Y. Sun, A. G. DiPasquale, A. R. Fox, A. L. Rheingold, J. S. Figueroa, Jr., Inorg. Chem. 2008, 47, 9010.

17. G. A. Bowmaker, J. V. Hanna, F. E. Hahn, A. S. Lipton, C. E. Oldham, B. W. Skelton, M. E. Smith, A. H. White, J. Chem. Soc. Dalton Trans. 2008, 13, 1710.

18. C. L. Raston, A. H. White, J. Chem. Soc. Dalton Trans. 1976, 2153.

19. F. A. Cotton, X. Feng, D. J. Timmons, Inorg. Chem. 1998, 37, 4066.

20. P. Pyykkö, Chem. Rev. 1997, 97, 597.

21. J. Rodriguez-Carvajal, Fullprof2000, Version 3.2, Laboratoire Léon Brillouin, 1997. 22. SADABS, SMART and SAINT, Bruker (1997) AXS Inc., Madison Wisconsin, USA. 23. G. M. Sheldrick, SHELXS97 and SHELXL97, University of Göttingen, Germany. 
Table 1. Important structural parameters of $\mathbf{1 a}$ and $\mathbf{1 b}$ including characteristic bond lengths $(\AA)$ and angles $\left(^{\circ}\right)$.

\begin{tabular}{lll}
\hline & $\mathrm{Cu}\left(\mathrm{NCNH}_{2}\right) \mathrm{Cl}(\mathbf{1 a})$ & $\mathrm{Cu}\left(\mathrm{NCNH}_{2}\right) \mathrm{Br}(\mathbf{1 b})$ \\
\hline color, form & white needles & white needles \\
space group & $P n m a($ no. 62) & Pnma (no. 62) \\
$a(\AA)$ & $8.2825(4)$ & $8.406(3)$ \\
$b(\AA)$ & $3.7275(1)$ & $3.9229(9)$ \\
$c(\AA)$ & $12.4534(4)$ & $12.656(3)$ \\
$V\left(\AA^{3}\right)$ & $384.48(2)$ & $417.4(2)$ \\
& & \\
$\mathrm{Cu}-\mathrm{X}$ & $2.47(3)(2 \times) ; 2.40(3)$ & $2.536(2)(2 \times) ; 2.510(3)$ \\
$\mathrm{Cu}-\mathrm{N} 1$ & $2.04(3)$ & $1.916(15)$ \\
$\mathrm{N} 1-\mathrm{C}, \mathrm{C}-\mathrm{N} 2$ & $1.10(4), 1.27(4)$ & $1.11(2), 1.35(2)$ \\
$\mathrm{Cu}-\mathrm{N} 1-\mathrm{C}$ & $177(2)$ & $177.2(19)$ \\
$\mathrm{N} 1-\mathrm{C}-\mathrm{N} 2$ & $177(2)$ & $180(2)$ \\
$\mathrm{N} 2-\mathrm{H} 2 \mathrm{~A}, \mathrm{~N} 2-\mathrm{H} 2 \mathrm{~B}$ & $0.89($ fixed $)$ & $0.882,0.865($ restrained $)$ \\
\hline
\end{tabular}

Table 2 Positional parameters (all atoms on $4 c, y \equiv 1 / 4$ ) and isotropic displacement parameters $\left(U_{\text {eq }}\right.$ in $\left.\AA^{2}\right)$ for $\mathbf{1 a}$ and $\mathbf{1 b}(\mathrm{X}=\mathrm{Cl}, \mathrm{Br})$ with standard deviations in parentheses.

\begin{tabular}{l|l|l|l|l|l|l}
\hline & \multicolumn{3}{|c|}{$\mathrm{Cu}\left(\mathrm{NCNH}_{2}\right) \mathrm{Cl}(1 \mathrm{1a})$} & \multicolumn{3}{c}{$\mathrm{Cu}\left(\mathrm{NCNH}_{2}\right) \mathrm{Br}(1 \mathbf{b})$} \\
\hline atom & \multicolumn{1}{|c|}{$x$} & \multicolumn{1}{|c|}{$z$} & \multicolumn{1}{c}{$U_{\text {eq }}$} & \multicolumn{1}{c}{$U_{\text {eq }}$} \\
\hline $\mathrm{Cu}$ & $0.1211(3)$ & $0.5593(2)$ & $0.0894(15)$ & $0.1091(3)$ & $0.5550(2)$ & $0.0758(10)$ \\
\hline $\mathrm{X}$ & $0.0468(5)$ & $0.3727(3)$ & $0.0169(14)$ & $0.0365(2)$ & $0.36269(14)$ & $0.0552(7)$ \\
\hline $\mathrm{N} 1$ & $0.3555(10)$ & $0.6110(11)$ & $0.082(2)$ & $0.3312(17)$ & $0.5892(15)$ & $0.076(5)$ \\
\hline $\mathrm{C}$ & $0.4833(11)$ & $0.6340(18)$ & $0.082(2)$ & $0.458(3)$ & $0.6131(13)$ & $0.056(4)$ \\
\hline $\mathrm{N} 2$ & $0.6290(10)$ & $0.6665(11)$ & $0.082(2)$ & $0.6132(17)$ & $0.6415(13)$ & $0.073(5)$ \\
\hline $\mathrm{H} 2 \mathrm{~A}$ & 0.643 & 0.738 & 0.088 & 0.6433 & 0.7066 & 0.087 \\
\hline $\mathrm{H} 2 \mathrm{~B}$ & 0.696 & 0.611 & 0.088 & 0.6903 & 0.5943 & 0.087 \\
\hline
\end{tabular}


Table 3 Hydrogen bond lengths $(\AA)$ and angles $\left(^{\circ}\right)$ for $\mathbf{1 a}$ and $\mathbf{1 b .}$

\begin{tabular}{llcccl}
\hline & $\mathrm{D}-\mathrm{H} \cdots \mathrm{A}$ & $d(\mathrm{D}-\mathrm{H})$ & $d(\mathrm{H} \cdots \mathrm{A})$ & $d(\mathrm{D} \cdots \mathrm{A})$ & $<(\mathrm{DHA})$ \\
\hline 1a & $\mathrm{N} 2-\mathrm{H} 2 \mathrm{~A} \cdots \mathrm{N} 1$ & 0.89 & 2.58 & 3.346 & 144.0 \\
1b & $\mathrm{N} 2-\mathrm{H} 2 \mathrm{~A} \cdots \mathrm{N} 1$ & 0.882 & 3.04 & 3.55 & 134.63 \\
\hline
\end{tabular}

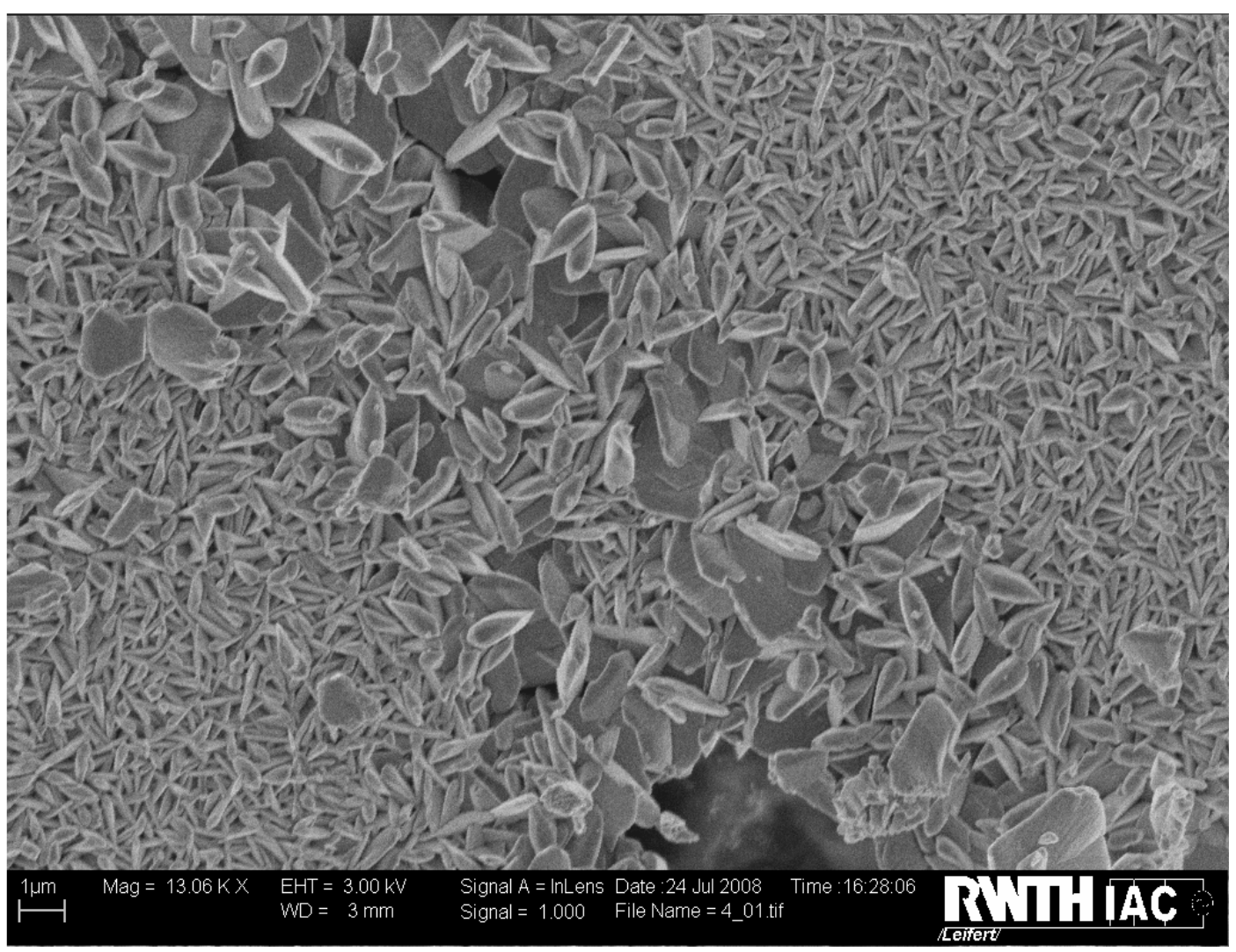

Figure 1. SEM micrograph of CuNCN. All micro-crystals appear as thin plates. 


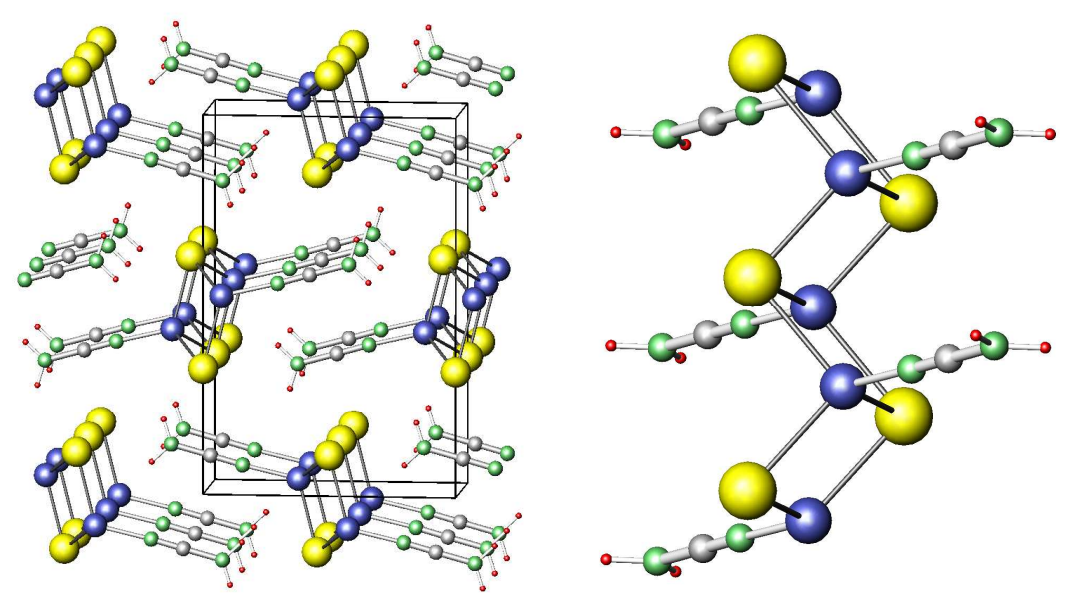

Figure 2. Packing diagram of the crystal structure of $\mathrm{Cu}\left(\mathrm{NCNH}_{2}\right) \mathrm{X}$ with $\mathrm{X}=\mathrm{Cl}$ and $\mathrm{Br}$. The left part shows a view along the crystallographic $b$ axis, and the right part displays the quasi one-dimensional copper-halogen chain. Color scheme: $\mathrm{Cu}$ in blue, $\mathrm{X}$ in yellow, $\mathrm{N}$ in green, $\mathrm{C}$ in grey, and $\mathrm{H}$ in red.

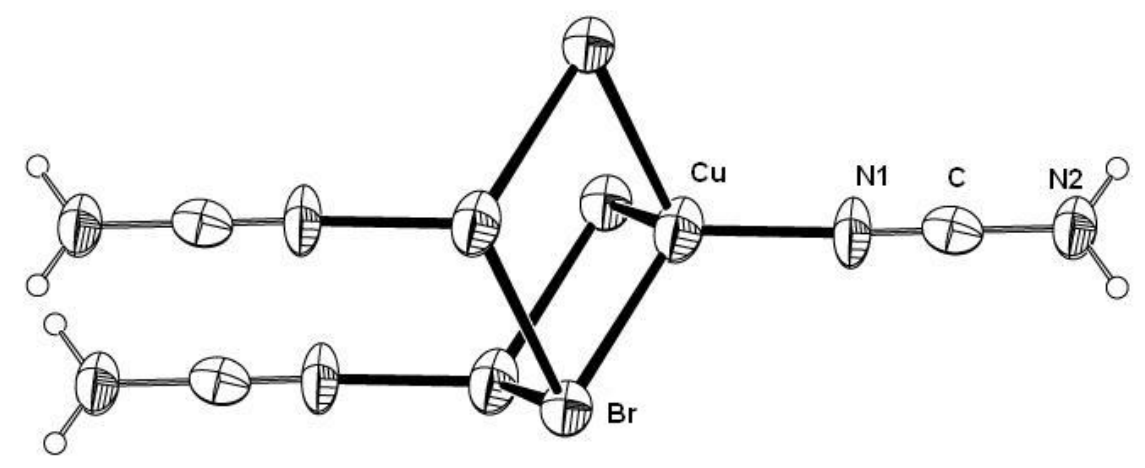

Figure 3. An ORTEP drawing of $\mathrm{Cu}\left(\mathrm{NCNH}_{2}\right) \mathrm{Br}$ with thermal ellipsoids at $30 \%$ probability level and $\mathrm{H}$ atoms as circles of arbitrary size. $\mathrm{Cu}\left(\mathrm{NCNH}_{2}\right) \mathrm{Cl}$ is iso-structural. 


\section{Page 13 of 25}

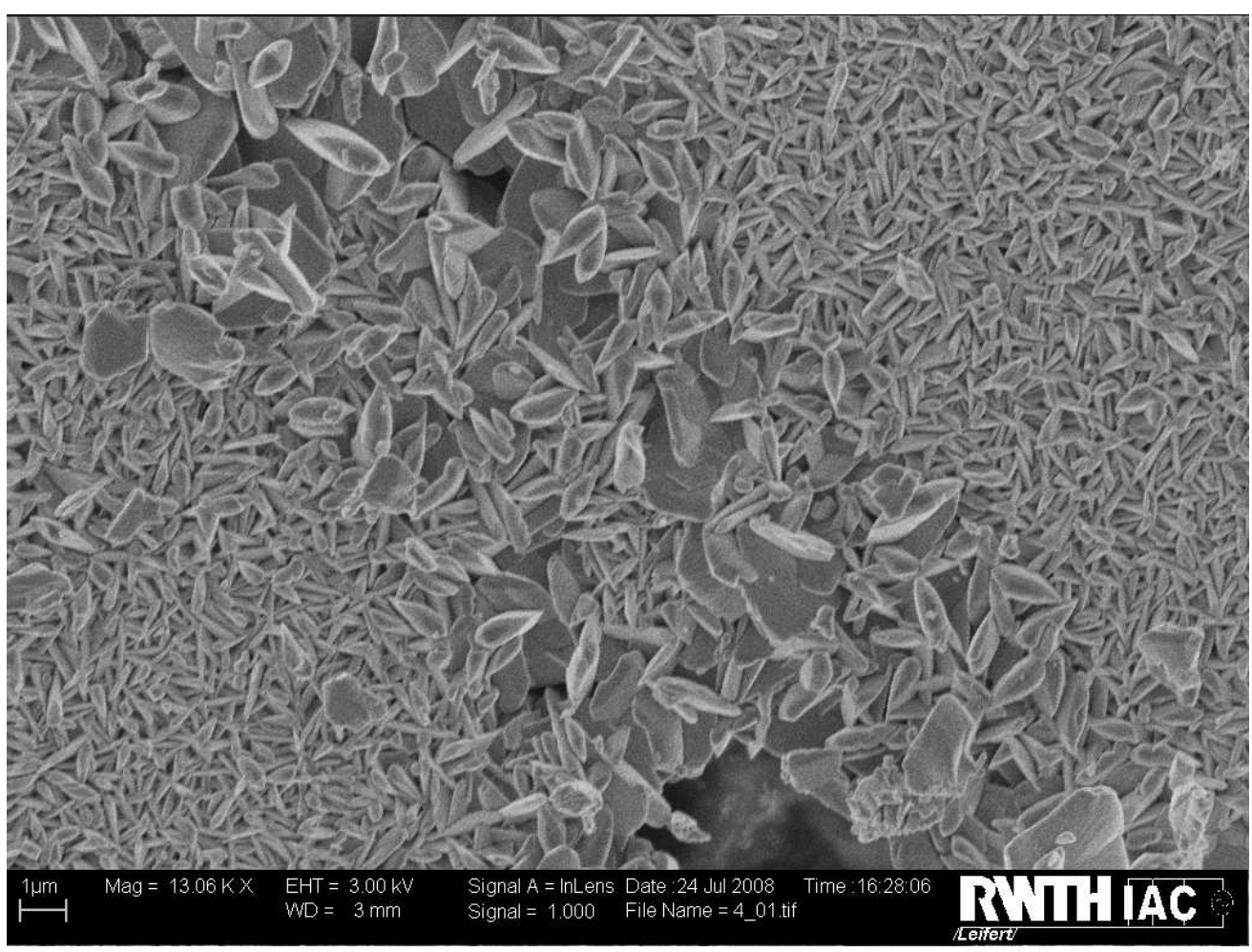

$361 \times 270 \mathrm{~mm}(72 \times 72 \mathrm{DPI})$

Wiley-VCH 


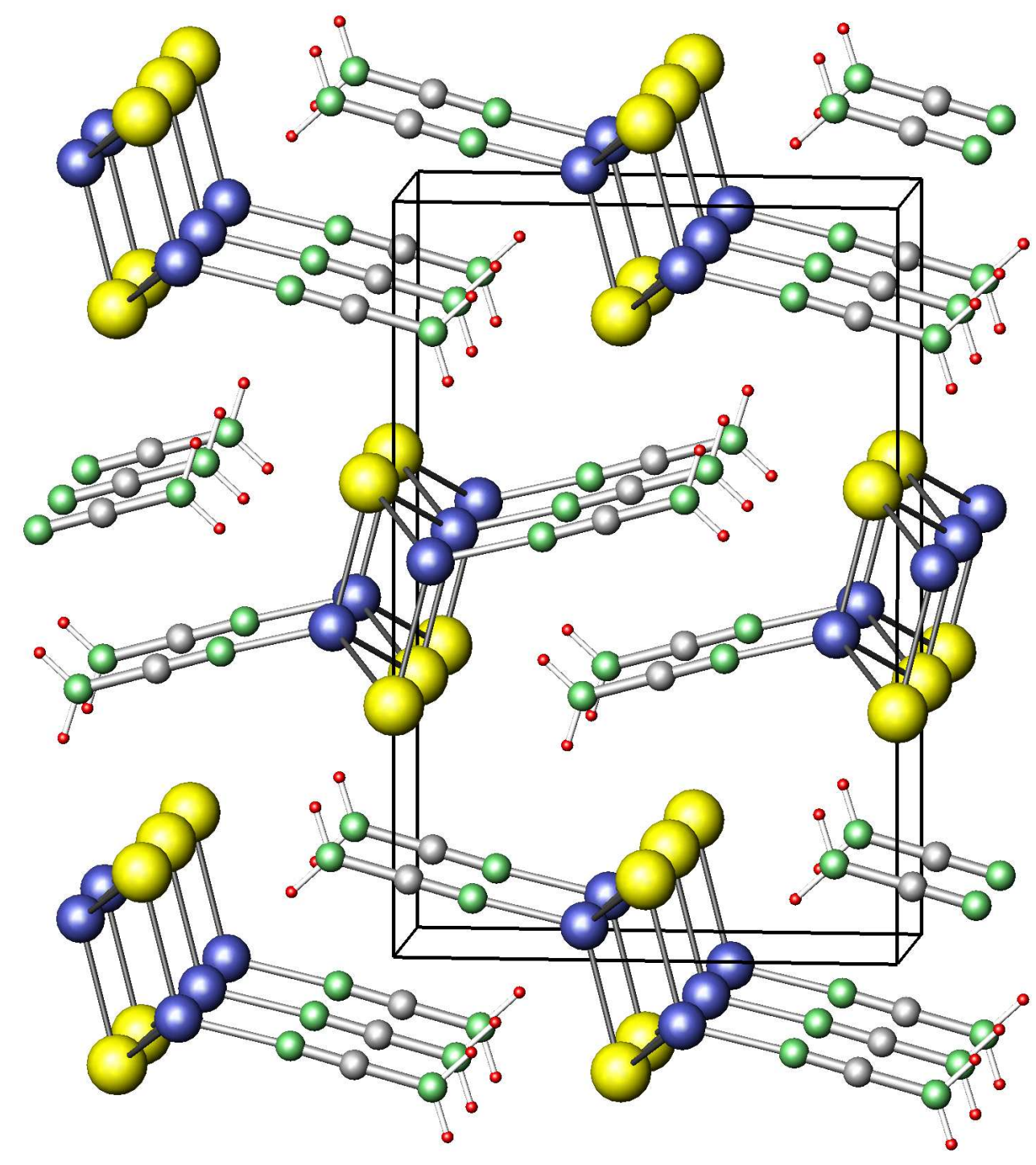

$127 \times 152 \mathrm{~mm}(300 \times 300$ DPI $)$

Wiley-VCH 


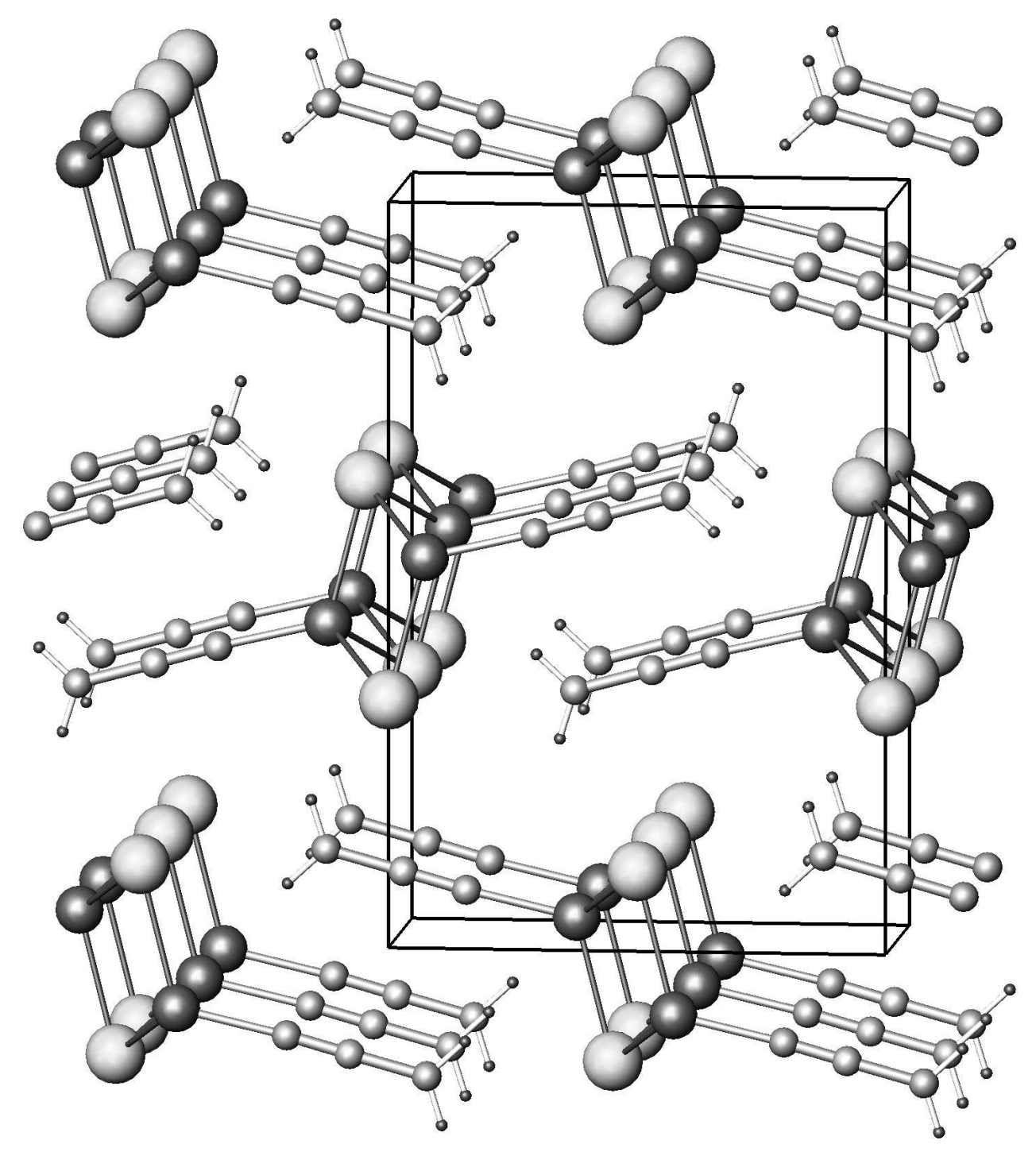

$127 \times 152 \mathrm{~mm}(300 \times 300 \mathrm{DPI})$

Wiley-VCH 


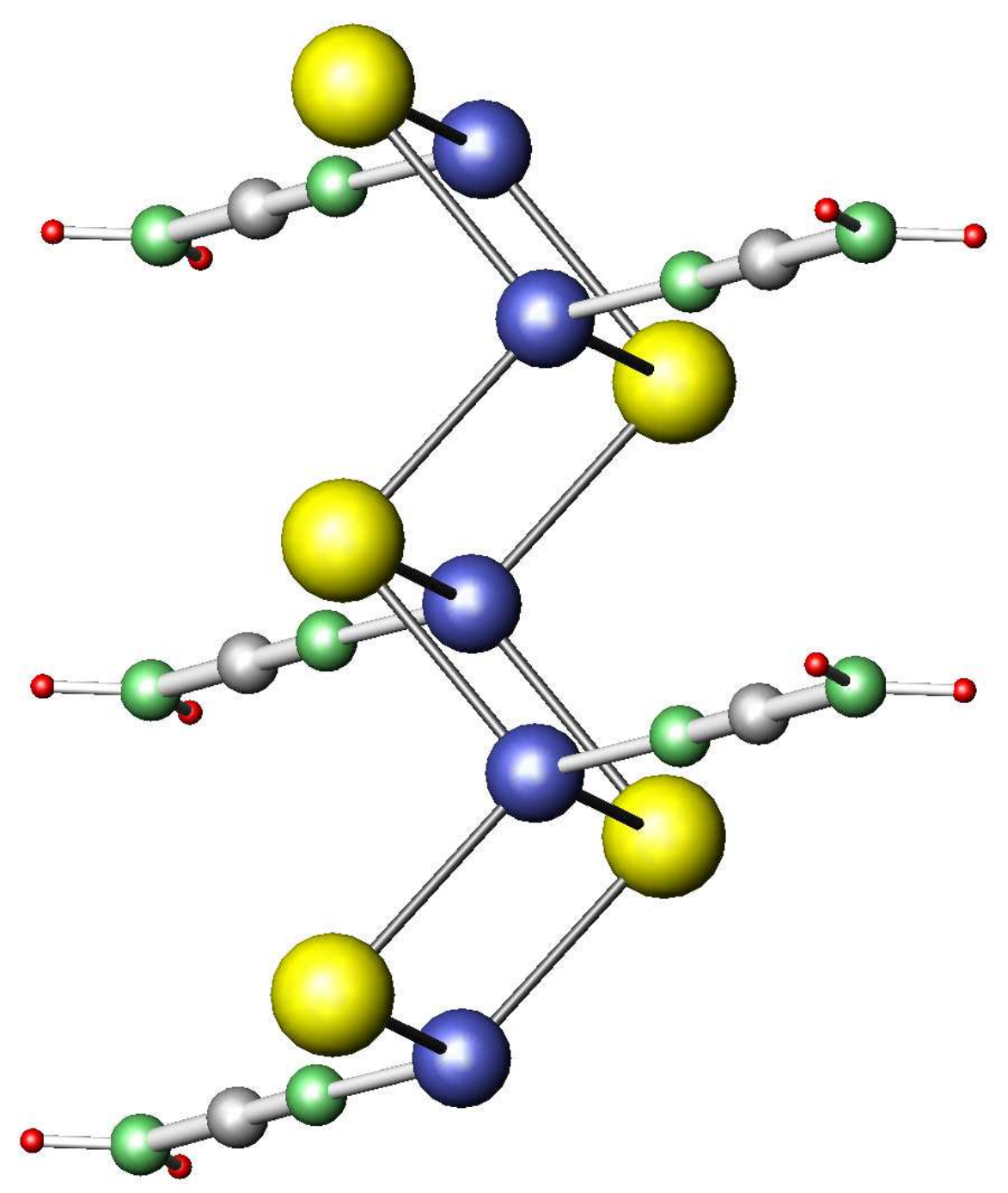

$76 \times 101 \mathrm{~mm}(300 \times 300 \mathrm{DPI})$

Wiley-VCH 


\section{Page 17 of 25}

1
2
3
4
5
6
7
8
9
10
11
12
13
14
15
16
17
18
19
20
21
22
23
24
25
26
27
28
29
30
31
32
33
34
35
36
37
38
39
40
41
42
43
44
45
46
47
48
49
50
51
52
53
54
55
56
57
58
60

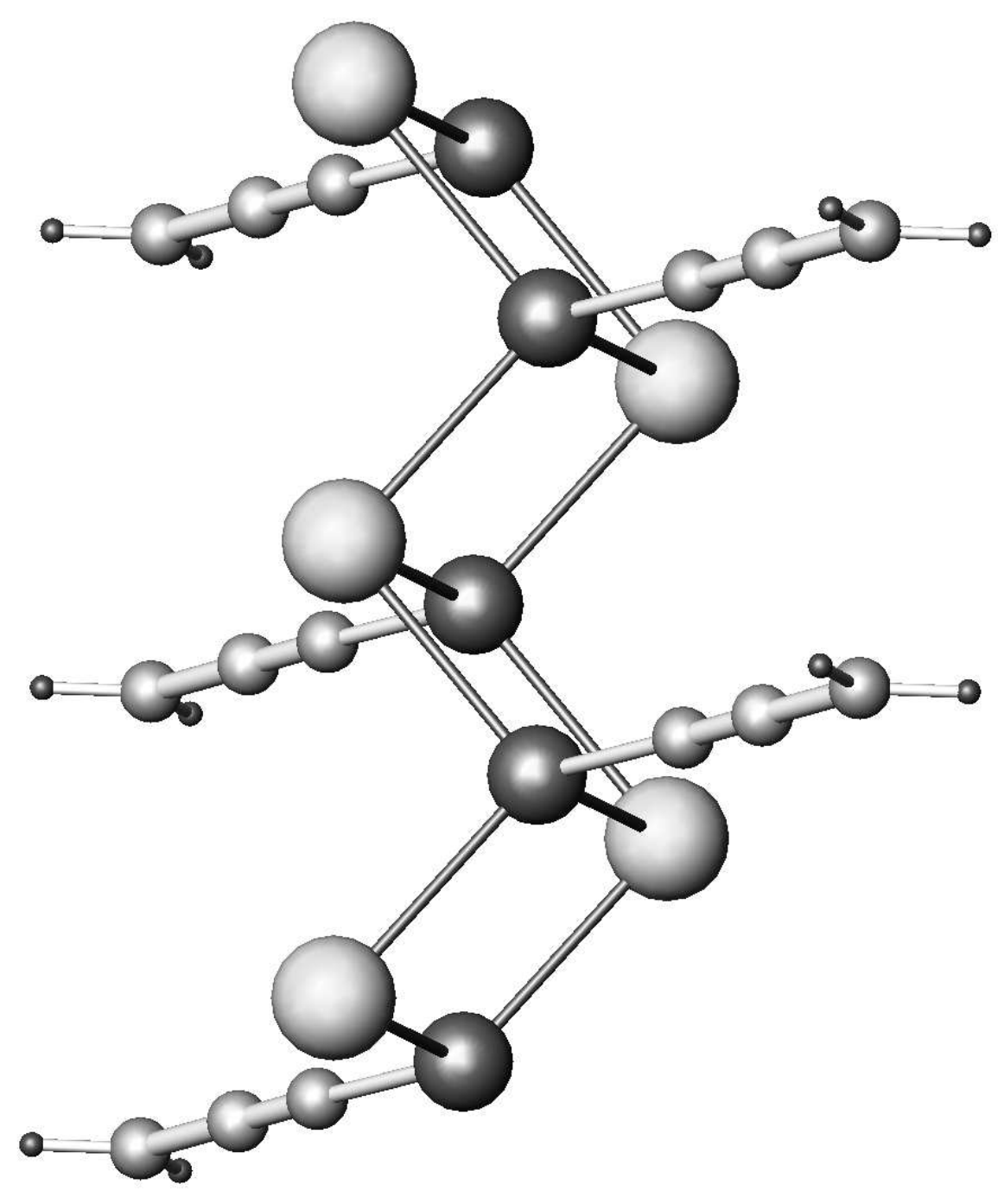

$76 \times 101 \mathrm{~mm}(300 \times 300 \mathrm{DPI})$

Wiley-VCH 


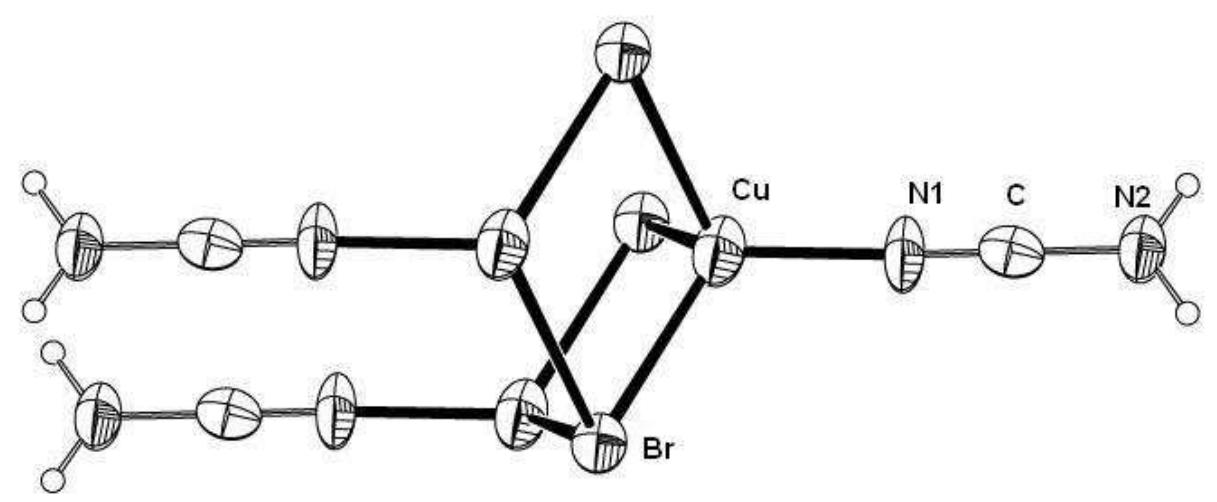

$190 \times 82 \mathrm{~mm}(96 \times 96 \mathrm{DPI})$ 
$139 \times 9 \mathrm{~mm}(360 \times 360 \mathrm{DPI})$ 


$$
\begin{aligned}
& 2\left[\mathrm{Cu}\left(\mathrm{NCNH}_{2}\right)_{2}\left(\mathrm{H}_{2} \mathrm{O}\right)_{2}\right]^{2+}+ 2 \mathrm{Cl}^{-}+\mathrm{SO}_{3}{ }^{2-} \longrightarrow \\
& 2 \mathrm{Cu}\left(\mathrm{NCNH}_{2}\right) \mathrm{Cl}+2 \mathrm{H}_{2} \mathrm{NCN}+\mathrm{SO}_{4}{ }^{2-}+3 \mathrm{H}_{2} \mathrm{O}+2 \mathrm{H}^{+}
\end{aligned}
$$

$149 \times 15 \mathrm{~mm}(360 \times 360 \mathrm{DPI})$ 
1

2

3

4

5

6

7

8

9

10

11

12

14

15

16

17

18

19

20

21

22

23

24

25

26

27

28

29

30

31

32

33

34

35

36

37

38

39

40

41

42

43

44

45

46

47

48

49

50

51

52

53

54

55

56

57

58

59

60
$2 \mathrm{Cu}\left(\mathrm{NCNH}_{2}\right) \mathrm{Cl}+2 \mathrm{NH}_{3} \longrightarrow \mathrm{Cu}_{2} \mathrm{NCN}+\mathrm{H}_{2} \mathrm{NCN}+2 \mathrm{NH}_{4} \mathrm{Cl}$ 


$$
2 \mathrm{Cu}_{2} \mathrm{NCN}+\mathrm{NH}_{3} \frac{\mathrm{NH}_{3} \cdot \mathrm{H}_{2} \mathrm{O} \mathrm{pH}>10}{150^{\circ} \mathrm{C}} \mathrm{Cu}_{4}(\mathrm{NCN})_{2} \mathrm{NH}_{3}
$$

\author{
$105 \times 10 \mathrm{~mm}(360 \times 360 \mathrm{DPI})$
}


1

2

3

4

5

6

7

8

9

10

11

12

13

14

15

16

17

18

19

20

21

22

23

24

25

26

27

28

29

30

31

32

33

34

35

36

37

38

39

40

41

42

43

44

45

46

47

48

49

50

51

52

53

54

55

56

57

58

59

60

$$
\mathrm{Cu}_{4}(\mathrm{NCN})_{2} \mathrm{NH}_{3}+2 \mathrm{H}_{2} \mathrm{NCN}+\mathrm{O}_{2} \longrightarrow 4 \mathrm{CuNCN}+2 \mathrm{H}_{2} \mathrm{O}
$$


$\mathrm{Cu}(\mathrm{II})$

$\mathrm{Cu}(\mathrm{I})$

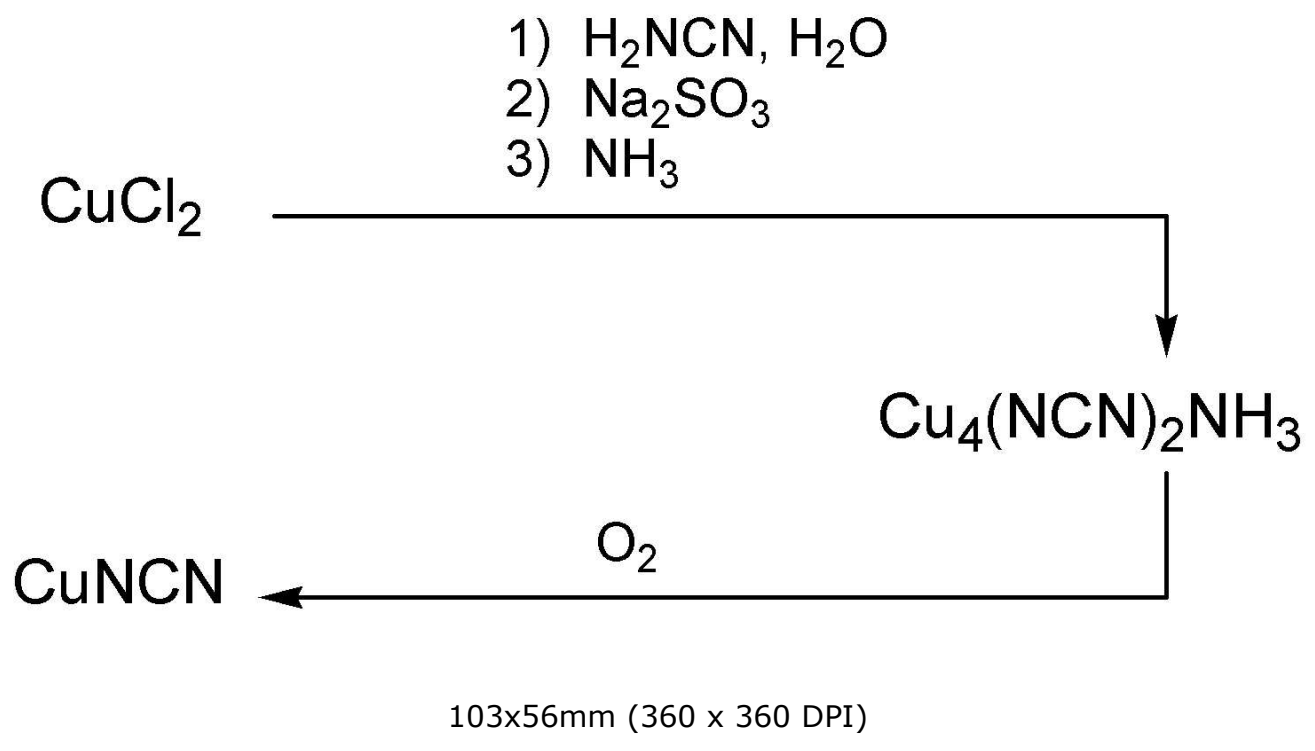

Wiley-VCH 
$\mathrm{Cu}(\mathrm{II})$

$\mathrm{Cu}(\mathrm{I})$

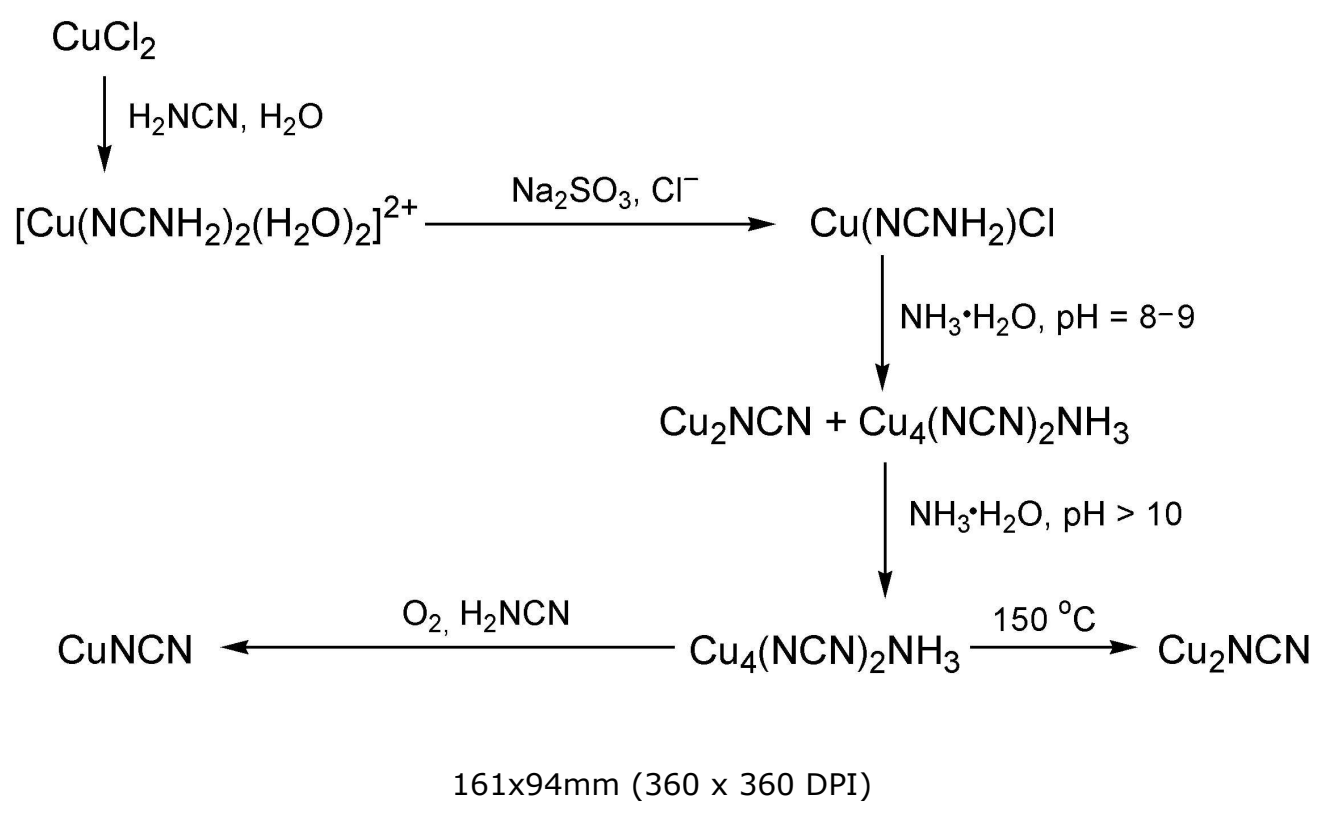

